Fixed Point Theory, 22(2021), No. 1, 431-452

DOI: $10.24193 /$ fpt-ro.2021.1.29

http://www.math.ubbcluj.ro/ nodeacj/sfptcj.html

\title{
COUPLED BEST PROXIMITY POINTS FOR CYCLIC CONTRACTIVE MAPS AND THEIR APPLICATIONS
}

\author{
BOYAN ZLATANOV \\ University of Plovdiv Paisii Hilendarski, \\ 24 "Tzar Assen" Str., Plovdiv, 4000, Bulgaria \\ E-mail: bzlatanov@gmail.com
}

\begin{abstract}
We enrich the known results about coupled fixed points and coupled best proximity points. We generalize the notion of ordered pairs of cyclic contraction maps and we obtain sufficient conditions for the existence and uniqueness of best proximity points. We get a priori and a posteriori error estimates for the coupled fixed points and for the coupled best proximity points, provided that the underlying Banach space has modulus of convexity of power type in the case of best proximity points, obtained by sequences of successive iterations. We illustrate the main result with an example. Key Words and Phrases Coupled best proximity points, uniformly convex Banach space, modulus of convexity, a priori error estimate, a posteriori error estimate, system of linear equations.
\end{abstract}

2020 Mathematics Subject Classification: 41A25, 47H10, 54H25, 46B20, 47H10.

\section{Conclusion}

It is interesting to apply the technique from the article for tripled fixed points and tripled best proximity points $[9,10,11,5,12]$, as well as for quadruple fixed points and quadruple best proximity points [23]. It will be also interesting if similar results could be obtained for coupled, tripled or quadruple fixed points in partially ordered metric spaces or best proximity points in partially ordered uniformly convex Banach spaces $[15,26]$. An open question can be to generalize the ideas from $[7,19]$ about coupled fixed or best proximity points.

\section{REFERENCES}

[1] B. Beauzamy, Introduction to Banach Spaces and their Geometry, North-Holland Publishing Company, Amsterdam, 1979.

[2] V. Berinde, Iterative Approximation of Fixed Points, Springer, Berlin, 2007.

[3] V. Berinde, Generalized coupled fixed point theorems for mixed monotone mappings in partially ordered metric spaces, Nonlinear Anal., 74(2011), no. 18, 7347-7355.

[4] V. Berinde, Coupled fixed point theorems for $\phi$-contractive mixed monotone mappings in partially ordered metric spaces, Nonlinear Anal., 75(2012), no. 6, 3218-3228.

[5] V. Berinde, M. Borcut, Tripled fixed point theorems for contractive type mappings in partially ordered metric spaces, Nonlinear Anal., 74(2011), no. 15, 4889-4897.

[6] V. Berinde, M. Păcurar, A constructive approach to coupled fixed point theorems in metric spaces, Carpathian J. Math., 31(2015), no. 3, 277-287. 
[7] V. Berinde, M.A. Petric, Fixed point theorems for cyclic non-self single-valued almost contractions, Carpathian J. Math., 31(2015), no. 3, 289-296.

[8] T.G. Bhaskar, V. Lakshmikantham, Fixed point theorems in partially ordered metric spaces and applications, Nonlinear Anal., 65(2006), no. 7, 1379-1393.

[9] M. Borcut, Tripled coincidence theorems for contractive type mappings in partially ordered metric spaces, Appl. Math. Comput., 218(2012), no. 14, 7339-7346.

[10] M. Borcut, V. Berinde, Tripled fixed point theorems for contractive type mappings in partially ordered metric spaces, Nonlinear Anal., 74(2011), no. 15, 4889-4897.

[11] M. Borcut, M. Păcurar, V. Berinde, Tripled fixed point theorems for mixed monotone Kannan type contractive mappings, J. Appl. Math., 2014(2014):120203, pp.9.

[12] Y.J. Cho, A. Gupta, E. Karapinar, P. Kumam, W. Sintunavarat, Tripled best proximity point theorem in metric spaces, Math. Inequal. Appl., 16(2013), no. 4, 1197-1216.

[13] R. Deville, G. Godefroy, V. Zizler, Smothness and Renormings in Banach Spaces, Pitman Monographs and Surveys in Pure and Applied Mathematics, 1993.

[14] A. Eldred, P. Veeramani, Existence and convergence of best proximity points, J. Math. Anal. Appl., 323(2006), no. 2, 1001-1006.

[15] A.J. Ellis, On partially ordering of normed spaces, Math. Scand., 23(1969), no. 1, 123-132.

[16] M. Fabian, P. Habala, P. Hájek, V. Montesinos, J. Pelant, V. Zizler, Functional Analysis and Infinite-Dimensional Geometry, Springer, New York, 2011.

[17] D. Guo, V. Lakshmikantham, Coupled fixed points of nonlinear operators with applications, Nonlinear Anal., 11(1987), no. 5, 623-632.

[18] A. Gupta, S.S. Rajput, P.S. Kaurav, Coupled best proximity point theorem in metric spaces, International J. Anal. Appl., 4(2014), no. 2, 201-215.

[19] A. Horvat-Marc, M. Petric, Examples of cyclical operators, Carpathian J. Math, 32(2016), no. $3,331-338$

[20] A. Ilchev, On an application of coupled best proximity points theorems for solving systems of linear equations, AIP Conference Proceedings, 2048(2018):050003.

[21] A. Ilchev, B. Zlatanov, Error estimates for approximation of coupled best proximity points for cyclic contractive maps, Appl. Math. Comput., 290(2016), 412-425.

[22] A. Ilchev, B. Zlatanov, Error estimates of best proximity points for Reich maps in uniformly convex Banach spaces, Annual of Konstantin Preslavsky University of Shumen, Faculty of Mathematics and Informatics, XIX C(2018), 3-20.

[23] E. Karapinar, V. Berinde, Quadruple fixed point theorems for nonlinear contractions in partially ordered metric spaces, Banach J. Math. Anal., 6(2012), no. 1, 74-89.

[24] A. Meir, On the uniform convexity of $L_{p}$ spaces, $1<p \leq 2$, Illinois J. Math., 28(1984), no. 3, 420-424.

[25] W. Sintunavarat, P. Kumam, Coupled best proxitmity point theorem in metric spaces, Fixed Point Theory Appl., 2012(2012):93.

[26] H. Yang, R.P. Agarwal, H.K. Nashine, Y. Liang, Fixed point theorems in partially ordered Banach spaces with applications to nonlinear fractional evolution equations, J. Fixed Point Theory Appl., 19(2017), no. 3, 1661-1678.

[27] B. Zlatanov, Error estimates for approximating of best proximity points for cyclic contractive maps, Carpathian J. Math., 32(2016), no. 2, 241-246.

Received: February 14, 2019; Accepted: February 7, 2020. 